University of Nebraska - Lincoln

DigitalCommons@University of Nebraska - Lincoln

Fall 2007

\title{
An Objective Aural-Relative in Middlemarch
}

Peter J. Capuano

University of Nebraska - Lincoln, pcapuano2@unl.edu

Follow this and additional works at: https://digitalcommons.unl.edu/englishfacpubs

Part of the English Language and Literature Commons

Capuano, Peter J., "An Objective Aural-Relative in Middlemarch" (2007). Faculty Publications -Department of English. 86.

https://digitalcommons.unl.edu/englishfacpubs/86

This Article is brought to you for free and open access by the English, Department of at DigitalCommons@University of Nebraska - Lincoln. It has been accepted for inclusion in Faculty Publications -- Department of English by an authorized administrator of DigitalCommons@University of Nebraska - Lincoln. 


\title{
An Objective Aural-Relative in Middlemarch
}

\author{
PETER J. CAPUANO
}

\begin{abstract}
Jubal . . watched the hammer, till his eyes,
No longer following its fall or rise,

Seemed glad with something that they could not see,

But only listened to-some melody,

Wherein dumb longings inward speech had found,

Won from the common store of struggling sound.

- George Eliot, "The Legend of Jubal"1
\end{abstract}

Midland England in the pre-Reform years may indeed look like the "very tuneless" place that Rosamond Vincy so positively assures Tertius Lydgate it is when they meet at the outset of Middlemarch (1871-72). ${ }^{2}$ She is correct. As Rosamond laments, "there are hardly any good musicians" in this community and perhaps even fewer "who sing at all well" (p. 159). Not a single professional musician lives in Middlemarch. The most perspicacious reader never witnesses an oratorio, concert, or symphony. Based on these facts, the reader of Middlemarch may expect to encounter only what the medical newcomer Lydgate calls "comic songs" rudely tapped on a drum in a faintly "rhythmic way" during his first encounter with Rosamond Vincy (p. 159). This is certainly a realistic representation of what life was like in a provincial English town in 1829.

But how much richer a world we experience in reading Middlemarch if we listen more closely to the melodic functions of sound despite its conspicuous deficit of professional music. ${ }^{3}$ Drawing on the work of the German philosopher Arthur Schopenhauer, George Eliot develops her most cherished themes of benevolence

Peter J. Capuano is a doctoral candidate in English Language and Literature at the University of Virginia. 
and sympathy within both a deeply musical and a realistic text. A primary contention of this essay is that musical sound-formally described and ideologically inscribed in Schopenhauerian philosophy—offers us an alternate mode of realism in a novel traditionally praised by critics for its imagistic precision. Middlemarch may very well be what George Levine calls the "fullest achievement of English realism," but I would further this claim by suggesting that the musical connection between Schopenhauer and George Eliot complicates our traditional understanding of sight-based realism even in this most "realistic" of English novels. ${ }^{4}$

Despite nineteenth-century England's reputation among European countries as "the land without music" (das Land ohne Musik), many Victorian writers depict music frequently. ${ }^{5}$ A number of critical works on music published within the last decade prove quite convincingly that Victorian Britain was richly musical despite the lingering assertions of the nation's tone deafness. ${ }^{6}$ George Eliot is among the most musical of Victorian authors because of her sustained emphasis on musical themes in Scenes of Clerical Life (1858), Adam Bede (1859), The Mill on the Floss (1860), and Daniel Deronda (1876). These particular novels, rather than Middlemarch, have attracted far more critical attention with regard to the subject of music because of their explicit representations of musical culture. ${ }^{7}$ Yet applying the same critical rigor to the structural and melodic functions of sound in Middlemarch allows us access to an important and alternate vector of reality within the novel. In particular, we may observe how George Eliot constructs an aural realism and refines her formulation of sympathy as a result of her knowledge and appreciation of Schopenhauer.

The details surrounding George Eliot's admiration for German philosophy have been amply discussed, but Schopenhauer's impact on her fiction in general, and on Middlemarch in particular, has largely escaped critical commentary. ${ }^{8}$ Schopenhauer devoted nearly one-quarter of his twelve-hundred-page principal work, Die Welt als Wille und Vorstellung (1818), to the aesthetic experience, and he was the first of the Continental philosophers to proclaim music as the highest of the arts. His emphasis on the aesthetic experience as a primary means of epistemological inquiry was particularly interesting to George Eliot. Long before his work was translated into English, Schopenhauer hailed music as the most moving and the most feeling of all the arts. "Music . . . stands alone, quite cut off from all the other arts," writes Schopenhauer, because in music "we do not recognise the copy or repetition of any Idea of existence in the world." Most important for this study, 
though, Schopenhauer posits a direct and necessary relationship between music and his much larger idea of the human Will: "music also, since it passes over the Ideas, is entirely independent of the phenomenal world, ignores it altogether, could to a certain extent exist if there was no world at all, which cannot be said of the other arts. Music is as direct an objectification and copy of the whole will as the world itself" ( $W W, 1: 333)$. For George Eliot, Schopenhauer brought together three great personal and scholarly passions: German philosophy, aesthetics, and music.

In her capacity as coeditor of The Westminster Review, Marian Evans (George Eliot's given name) first publicly acknowledged her admiration for Die Welt als Wille und Vorstellung when she chose to publish John Oxenford's pioneering essay on Schopenhauer in April 1853. Oxenford's essay, entitled "Iconoclasm in German Philosophy," not only introduces England to the virtually undiscovered "misanthropic sage of Frankfort," but also reveals George Eliot's desire to explicate the brilliance of Die Welt als Wille und Vorstellung to a new audience. ${ }^{10}$ The article incorporates large sections of Schopenhauer's work (translated in English) as it argues for the importance Schopenhauer's "clearly worded," "comprehensible system" of aesthetic philosophy. ${ }^{11}$ Although the article does not explicitly discuss music, it is important for George Eliot and for her composition of Middlemarch that there are connections between the "ideal" artist and the virtue of sympathy. Oxenford states that Schopenhauer's ideal artist "is he whose heart beats with sympathy for all creatures around him, practically if not theoretically acknowledging them as manifestations of the same great Will as himself." 12 George Eliot's own nonfiction writing for The Westminster Review provides an early example of her parallel interest in the artist's unique relationship to sympathy by way of sound. The truly great artist, George Eliot says, teaches "by giving us his higher sensibility as a medium, a delicate acoustic or optical instrument, bringing home to our coarser senses what would otherwise be unperceived by us." 13

A Schopenhauerian sense of music provides George Eliot with the appropriate medium, the "delicate acoustic . . . instrument" as she calls it, with which to accomplish her most ambitious goal of instilling the reader of Middlemarch with sympathetic feeling. George Eliot foregrounds this lofty goal in the novel's Prelude. It is in her Prelude that her narrator challenges the reader to imitate Saint Theresa, who "soared after some illimitable satisfaction, some object which would never justify weariness, which would reconcile self-despair with the rapturous consciousness 
of life beyond the self" (p. 3). Sympathy-what George Eliot succinctly calls "consciousness of life beyond the self" - is Dorothea Brooke's most solemn objective, though she learns to focus such consciousness from limitless benevolence to her role as a mother. A Schopenhauerian sense of musicality nonetheless influences the ways in which George Eliot provides her readers with the feeling of sympathy.

Well before Thomas Carlyle enigmatically conflated the visual and the aural when he wrote, "See deep enough, and you see musically," ${ }^{14}$ Schopenhauer delineated his philosophy of an aural reality:

[music] never expresses the phenomenon, but only the inner nature, the in-itself of all phenomena, the will itself. It does not therefore express this or that particular and definite joy, this or that sorrow, or pain, or horror, or delight, or merriment, or peace of mind; but joy, sorrow, pain, horror, delight, merriment, peace of mind themselves ... In the determinateness of the real, [pictures of human life] represent that which music expresses in the universality of mere form . . . the object of perception . . . contain[s] particulars only as the first forms abstracted from perception, as it were, the separated shell of things; thus they are, strictly speaking, abstracta; music, on the other hand, gives the inmost kernel which precedes all forms, or the heart of things.

(WW, 1:338-40)

For Carlyle, who read Schopenhauer before his work was translated into English, "the Poet is he who thinks" in "musical Thought." ${ }^{15}$ Will Ladislaw's definition of the poet is also decidedly musical and Schopenhauerian. "To be a poet," Will says in an early conversation with Dorothea, "is to have a soul quick to discern ... that discernment is but a hand playing with finely ordered variety on the chords of emotion" (p. 223). Like Dorothea, Will eventually focuses his enthusiasm from poetry to politics but, as I shall show, he remains one of the novel's most musically inclined characters.

In Schopenhauer's view, the discovery of the Will in the self relies upon the potential for imaginative reflection in order to move beyond the illusion of isolated individuality. George Eliot works to dismantle this notion of isolation throughout Middlemarch's plot. She draws on Schopenhauerian philosophy as she defines her 
own profound notion of sympathy in Middlemarch's Prelude. Saint Theresa sorts out the "tangled circumstance" of individual and collective love as she strives to achieve "rapturous consciousness of life beyond the self" (p. 3). The dynamic properties of music allow George Eliot the range and timbre of expression necessary to display realistically the complex set of tangled experiences that make up the sprawling Middlemarchian experience-even in one where benevolent desire eventually becomes channeled into specific local action. Although it is structurally obvious, it is worth noting how George Eliot frames the novel with the operatic terminology of a prelude and a finale. These musical terms do not simply fulfill a musical aesthetic for George Eliot, however; in terms of narrative, they perform the musical functions for which they are named.

George Eliot's Prelude is brief and instrumental in the sense that it contains no external dialogue and its rapidly shifting spatial and temporal distance creates a tone of improvisation-an important component of any musical prelude. We abruptly encounter "the history of man," "the varying experiments of Time," "Saint Theresa," and also the "later-born Theresas" (p. 3). Phyllis Weliver, though not speaking of Middlemarch's Prelude, effectively points out music's more general ability to accommodate this complex temporal sequence: "Music becomes a perfect metaphor for this process, especially as the universal, non-causal sense of time is difficult to discuss verbally or within a narrative structure that depends upon the reader making causal connections between the story's events." ${ }^{16}$ At this early point in Middlemarch, George Eliot's alignment of prose with a musical Prelude is significant precisely because the reader does not yet have access to the story's events, making causal connections impossible. In this sense, the brief Prelude sweeps through the vast territory of the novel's upcoming events and themes: "domestic reality," the "life of mistakes," and "vague ideal" (p. 63).

George Eliot begins Middlemarch with a Prelude, but she relies on musical precepts to marshal her major themes-even at plot junctures-so that the narrative design resembles musical movement. Susan McClary, in her groundbreaking study of feminist musical criticism, argues that "tonality itself-with its process of instilling expectations and subsequently withholding promised fulfillment until climax-is the principal musical means during the period from 1600 to 1900 for arousing and channeling desire." 17 Music establishes a pattern of dissonance within a tonal system and withholds harmonic resolution in a way that creates 
anticipation for the listener. George Eliot orchestrates a similar, though equally complex, musical atmosphere in Middlemarch. Her characters make up an expansive rhythmic system wherein each character's subtly defined level of musical responsiveness corresponds to a distinct chord within the community chorus. In a more general sense, George Eliot's characters in Middlemarch can be assigned a roughly musical (and sympathetic) index based on the level of their responsiveness or unresponsiveness to music. With the interaction between different characters-differing levels of character musicality-George Eliot creates specific instances of tonal dissonance while she withholds resolution and harmonic consonance. McClary appropriately points out that "[m]usic is also very often concerned ... with mapping patterns through the medium of sound that resemble those of sexuality." 18

These specific qualities of music apply to the design of George Eliot's romantic plotting. For example, George Eliot begins by establishing a level of screeching dissonance with both of Middlemarch's early romantic pairings: Edward Casaubon and Dorothea, Tertius Lydgate and Rosamond. Here, an excerpt from Arnold Schoenberg's Theory of Harmony is relevant: "The dualism presented by major and minor has the power of a symbol suggesting high forms of order: it reminds us of male and female and delimits the spheres of expression according to attraction and repulsion." ${ }^{19}$ Indeed, there exists in Middlemarch's romantic parings an aural stridency beyond their physical incongruity. Despite all of George Eliot's unsightly descriptions of Casaubon, his frigid unresponsiveness to music is more amplified even than his warted appearance. Not only does Dorothea describe him as "not fond of the piano," but Casaubon refers to piano music disparagingly as "measured noises" that diminish his concentration (p. 65). Casaubon possesses a harpsichord at Lowick, but it is buried beneath a dusty stack of books. Perhaps Mrs. Cadwallader phrases it best when she reports that "[s]omebody put a drop [of his blood] under a magnifying-glass, and it was all semicolons and parentheses" (p. 71). Casaubon's musical unresponsiveness translates more generally into a lack of enthusiasm for anything except his scholarly "work." His decision to spend his honeymoon researching Vatican documents is indicative of the marriage's barely audible "tenor"-aptly one of Casaubon's fastidiously chosen words in his epistolary proposal to Dorothea.

My point in analyzing the musical inclinations of Middlemarch's characters extends beyond the individual levels of their sympathy. I am interested also in how different forms of musical 
characterization operate within the larger framework of the novel. On a structural level, I am suggesting that George Eliot mediates the interaction between musically disparate but romantic pairs such as Dorothea-Casaubon and Rosamond-Lydgate in such a way that creates a subtle but distinctive tonal dissonance. Just as tonal dissonance is required to sustain variation in a musical harmony, George Eliot's thematic and character-based dissonance in Middlemarch is required to facilitate her narratological aims.

What George Eliot calls "concords and discords, cadences and cries" in her poem "The Legend of Jubal" (a poem she was composing while writing parts of Middlemarch), she incorporates into the structure of the novel's romantic parings. ${ }^{20}$ The inelegance of the Dorothea-Casaubon marriage is certainly an ocular impropriety, but it is even more an aural discordance. The proposition of marriage is typically one of the most riveting spectacles in the Victorian novel, but with Dorothea and Casaubon we see almost nothing. Instead, we hear the dull and inanimate words of Casaubon's epistolary proposal. This, along with Dorothea's similarly unremarkable epistolary acceptance, works to ensure a soundless, dispassionate, and academic betrothal scene. Casaubon makes no profession of love; only what his letter identifies as an "accurate statement of [his] feelings" (p. 44). This epistolary marriage proposal at once prevents our seeing and promotes our hearing of the union. We hear the clear and resonant awkwardness of Casaubon's betrothal speech in chapter 5: "the frigid rhetoric at the end [of the speech] was as sincere as the bark of a dog, or the cawing of an amorous rook" (p. 50). We read Casaubon's speech, but even here George Eliot steers our attention from the words to the grating sounds of the barking dog and the cawing rook. Surprisingly, in Casaubon's gelid words, Dorothea actually hears something quite different, something far beyond the decidedly "thin music" of his wooing: "Dorothea's faith supplied all that Mr. Casaubon's words seemed to leave unsaid: what believer sees a disturbing omission or infelicity? The text, whether of prophet or of poet, expands for whatever we can put into it, and even his bad grammar is sublime" (p. 50). With this in mind, it is possible to consider Dorothea's mistake concerning Casaubon not only as "errors in seeing," as J. Hillis Miller correctly refers to them, but also as errors engendered by the presumptiveness of her auditory imagination. ${ }^{21}$ The shortsightedness of both Dorothea and Lydgate in Middlemarch, along with the narrator of George Eliot's Impressions of Theophrastus Such (1879), reveal that "powerful imagination is not false outward vision, but intense inward rep- 
resentation." ${ }^{22}$ For George Eliot, the ocular imagination is quite different from the auditory imagination. Her field of "intense inward representation" extends beyond external perception to include, most notably, the aural.

The irony that George Eliot creates in the Dorothea-Casaubon marriage has a particularly aural component, and its dissonant reverberations are required to achieve the novel's melodic objectives. Like Dorothea, readers hear Casaubon's words and know that they sound like neither prophet nor poet. Dorothea and Casaubon certainly "look" like an awkward pair-Sir James Chettam, Celia Brooke, and Mrs. Cadwallader assure us of this-but my contention is that their narrative interaction produces an aural dissonance that resonates beyond their physical incompatibility. Their decorous conversations sound especially grating compared to the mellifluous discussions between Dorothea and Ladislaw about the nuances of art. With Dorothea as a sort of musical fulcrum, the alternation from aural dissonance with Casaubon to harmonic consonance with Ladislaw creates a subtle but important narrative device. It allows George Eliot to sustain a triangular love scenario involving her heroine to a Victorian audience without the implications of sexual desire for two men. Instead, sexual desire is appropriated by Dorothea's attraction to musical harmony. According to McClary, the theoretical writings of Heinrich Schenker often draw explicitly on analogies to sexuality. Throughout Harmony (1906), for example, Schenker "describes musical logic - whether motivic or harmonic - as the product of "procreative urges." ${ }^{23}$ Especially given the ending of the novel with a child born to Will and Dorothea, Schenker's emphasis on "the biological aspect of music" seems germane. ${ }^{24}$

As Barbara Hardy has pointed out, there is a strong asexual element in Dorothea's relationship with Casaubon, but even this does not alter the fact that Dorothea is married and yet attracted to another man. ${ }^{25}$ Attraction to Ladislaw is brokered in terms of the desire for musical as well as personal harmony. Not only is the timbre of conversation between Will and Dorothea more pleasing to the ear, but George Eliot also presents their inherent musical personalities in harmonic consonance. It fits harmonically that a woman capable of sobbing at the sound of the Freiberg organ (p. 68) falls in love with a man whose entire world can be changed by hearing one stroke drawn by the bow across a violin: "Will, too, was made of very impressible stuff. The bow of a violin drawn near him cleverly, would at one stroke change the aspect of the world for him" (p. 388). Moreover, even what little information we receive 
about Ladislaw's heritage is rendered in terms of the aural. Will cryptically describes his grandfather's most salient attributes to Dorothea: "[he] was a patriot—a bright fellow—could speak many languages-musical-got his bread by teaching all sorts of things" (p. 365). Try as he may to defend the poet's ability to articulate emotions with words in an early conversation with Dorothea, Will uses a musical metaphor in his definition of the poet: "To be a poet is to have a soul quick to discern, that no shade of quality escapes it, and so quick to feel, that discernment is but a hand playing with finely ordered variety on the chords of emotion-a soul in which knowledge passes instantaneously into feeling, and feeling flashes back as a new organ of knowledge. One may have that condition by fits only" (p. 223). Of course, "that condition" to which Ladislaw refers is the same condition of musical sublimity that moves Dorothea to tears at the sound of the organ at Freiberg. It is a similar paroxysm that repeatedly turns even the scientific Lydgate into an "emotional elephant" and deafens him to Rosamond's musical legerdemain (p. 267).

Since Lydgate is a scientist and Middlemarch emphasizes the scientific perspective, it is appropriate that George Eliot renders Lydgate's mistake with Rosamond, like Dorothea's, not as an insufficiency in seeing but as an imperfection in hearing. Eyes perceive the visual field through a continual process of stabilization where a number of alternating foci are arranged to form one view. The auditory field arranges tonal progression-dissonance and consonance-in a similar way so that we anticipate and desire harmonic resolution. In Schenker's view, "tonal compositions arouse desire and the surface strategies that postpone gratification." ${ }^{26}$ Like music, Middlemarch's narrative structure sets up aural anticipations and then satisfies them. Romantic and even filial pairings produce a stridency or harmony depending almost entirely on a character's musicality. Dorothea and Casaubon "sound" terrible in conversation together, but the same can be said of Lydgate and Rosamond as we hear the sound of Lydgate's growing disappointment with Rosamond's underhanded dealings with her new husband's family. The scenes of tonal dissonance mesh with sections of anticipated, character-based harmony as the narrative progresses. For example, Dorothea's passionate discussions with both Ladislaw and Lydgate are pleasing to ear and emotion alike. It is appropriate in this sense that George Eliot renders the final reunion of Dorothea and Ladislaw in terms of a musical experience: "Let the music which can take possession of our frame and fill the air with joy for us, sound once more-what 
does it signify that we heard it found fault with in its absence?" (p. 631). Even the eventual union of Fred Vincy and Mary Garth is harmonic. Mary has no musical training, but she nonetheless fulfills an important harmonic role by tolerating Fred's untutored enthusiasm for the flute.

Rosamond Vincy has a similar ambivalence to music, though we (like Lydgate) may be tempted to think otherwise because she is constantly performing music. Unlike Casaubon, however, Rosamond is not innocuously tone-deaf; hers is a far larger fault in George Eliot's view, because she understands music intellectually yet she remains profoundly unmoved by its presence. Rosamond studied music under a competent master at Mrs. Lemon's school, and she performs her former teacher's music admirably at the Vincy social gatherings: "Rosamond, with the executant's instinct, had seized his manner of playing, and gave forth his large rendering of noble music with the precision of an echo. It was almost startling, heard for the first time. A hidden whole seemed to be flowing forth from Rosamond's fingers" (p. 161). George Eliot's diction is resonant and noteworthy in this example. Rosamond does not enthusiastically embrace the teachings of her master at Mrs. Lemon's school. Instead, she "seize[s] his manner of playing" (emphasis added). In this expression, George Eliot reveals her disdain for Rosamond's misuse-and even abuse-of music for her own gain. Because of her superficial, though studied, relationship to music, Rosamond cannot experience the sublime state of consciousness beyond the self that comes, according to Schopenhauer, when music connects us "with the inmost nature of the world" ( $W W, 1: 331)$. Rosamond experiences music only within what Schopenhauer calls the abstractum - "the separated shell of things." For this reason, Rosamond offers not "noble" music to the people of Middlemarch, only an animated but merely imitated "rendering of noble music."

George Eliot exhibits this musical subterfuge most poignantly at the moments in the novel when Rosamond uses her talent deliberately for personal gain. In these instances, Rosamond appears most detached from her music precisely because she manipulates, and so violates, the music to accommodate her audience. Her singing and piano playing before Featherstone and Lydgate provide two such examples early in the novel. The first occurs between Featherstone and Rosamond: "Mr. Featherstone asked Rosamond to sing to him, and she herself was so kind as to propose a second favourite song of his-'Flow on, thou shining river'-after she had sung 'Home, sweet home' (which she 
detested)" (p. 116). Rosamond expresses a similar attitude toward musical performance later in the novel: "Her singing was less remarkable, but also well trained, and sweet to hear as a chime perfectly in tune. It is true she sang 'Meet me by the moonlight' and 'I've been roaming'; for mortals must share the fashions of their time, and none but the ancients can be always classical. But Rosamond could also sing 'Black-eyed Susan' with effect, or Haydn's canzonets, or 'Voi che sapete', or 'Batti, batti-she only wanted to know what her audience liked" (p. 161). In both scenes, George Eliot relegates Rosamond's polished talents to the more crass (and unfeeling) realm of entertainment. She plays methodically, and with ostensible pleasure, even the music she detests at those times when there is a chance for personal advancement. She goes with Fred to Mr. Featherstone's largely because she speculates that time spent with her sick uncle will improve her chances of meeting the new, well-bred Doctor Lydgate. In the second scene, in which Rosamond plays nearly perfectly, the narrator regards Rosamond's talent as a peculiar form of musical prostitution, wherein the performer engages in the act in exchange for something else-something more important to the artist than the act itself. She is willing to play "Black-eyed Susan" or Haydn's canzonets, though she does not care which; "she only want[s] to know what her audience liked." It is not so important that Rosamond's musical appearances lack originality as it is that they lack feeling - and feeling for both Schopenhauer and George Eliot is required for the artist to invoke sympathy.

It is one of the great ironies of the novel, and certainly one of George Eliot's most deft artistic achievements, that Middlemarch's most musical characters are not "musical" in the technical sense of the term. Instead, they are the characters for whom music inspires deep Schopenhauerian feelings of egoless sympathy. Will Ladislaw, Tertius Lydgate, Caleb Garth, and Dorothea Brooke lack formal musical training, but George Eliot instills in them a distinctly Schopenhauerian appreciation for musical reality. Each of these characters, by way of their musicality, possesses what Schopenhauer calls "the determinateness of the real." For George Eliot, the capacity to feel musically is the capacity to live as a compassionate human being. Though Dorothea dislikes the shallow drawing room piano renditions (of the kind Rosamond prefers), her poignant sobbing experience while listening to the great organ at Freiberg registers her more essential musicality. Similarly, even Lydgate's scientific version of sympathy can be connected to an untutored appreciation for music on a meta- 
physical level. The narrator tells us in the initial conversation with Rosamond that "[t]he only pleasure [Lydgate] allowed himself during the latter part of his stay in Paris was to go and hear music" (p. 159). When Rosamond assumes his well-bred status means academic training in Paris, Lydgate inadvertently provides us with an Eliotic précis on behalf of musical sympathy: "No, I know the notes of many birds, and I know many melodies by ear; but the music that I don't know at all, and have no notion about, delights me-affects me. How stupid the world is that it does not make more use of such a pleasure within its reach!"' (p. 159). It is so much less important to George Eliot that Lydgate cerebrally understand his musical experiences than it is that they delight and affect him. We know from the previous chapter outlining his medical background that Lydgate has an enthusiastic and sympathetic sense of duty beyond himself: "to do good small work for Middlemarch, and great work for the world" (p. 149).

The musical also illuminates the essential differences between Lydgate and Rosamond. Rosamond performs whatever her audience likes, while Lydgate is content as a medical maverick studying in Paris, not for the social cachet but for a genuine enthusiasm for advancing the medical profession of scientific care. If Lydgate and Rosamond are separate species, as the text suggests, music is their biological fault line. Even though Rosamond's music is not genuine, it is a sign of Lydgate's sincere feeling that George Eliot describes him as an "emotional elephant" around her music. George Eliot reveals the emotional power of music as she chronicles a situation where an impartial scientist makes a poor matrimonial decision based not on what he sees but on what he hears. Lydgate's scientific perspective relies on an ability to recognize and maintain precise (and often visual) boundaries between fact and feeling. Lydgate's error, like Dorothea's, though, is not one of seeing but one of hearing. He mistakes what he sees in Rosamond for what he hears in her music. For characters with elephantine levels of emotion, music is a vehicle to the ineffable feeling of consciousness beyond the self. Music provides the point of access, if only in sporadic moments of paroxysm, for George Eliot's characters to go beyond the abstracta to what Schopenhauer calls the inmost kernel that precedes all forms, or the heart of things.

Not only does George Eliot use music in the novel's general structure, but more specifically she also uses musical tags to differentiate her characters. ${ }^{27}$ Each character's voice holds a distinct position in a rhythmic scale: Dorothea speaks in a "rec- 
itative" tone, Casaubon in a "measured, official tone," Lydgate in a "baritone," Celia in a "placid guttural," Mrs. Waule in a "woolly tone," and Naumann in "dithyrambs" (pp. 47, 197, 592, 820, 307, 217). Alison Byerly rightly connects what she calls "voice privileging" to a more general trend in George Eliot's fiction. "Eliot took the philosophical concept of "voice," Byerly says, "and literalized what was essentially a symbol of authenticity into an actual expression of authenticity." 28 But in Middlemarch, voice does more than express authenticity; George Eliot requires voice to carry the freight of her characters' sympathy as well. The musicality of the voices affords us with a still more precise indication of a character's ability to feel sympathetically. George Eliot fuses voice and music to the extent that voice rhythm becomes a remarkably reliable index by which to plumb the musical and sympathetic depth of a given Middlemarcher. Musical dynamics clearly define the sympathetic differences between Celia and Dorothea at the outset of the novel, for instance. Celia, who speaks "always with the same quiet, staccato evenness," cares more about Casaubon's physical appearance than she does for Dorothea's plans for cottage building (p. 32). George Eliot also expresses Celia's lack of emotional feeling as a lack of musical understanding: "[Celia] never could understand how well-bred persons consented to sing and open their mouths in the ridiculous manner requisite for that vocal exercise" (p. 32). Even worse is the case of Rosamond. She clearly does understand music, and she uses musical tone deftly in her singing. However, the more genuine expression of her "authenticity"-her speaking voice-remains conspicuously flat throughout the novel.

Casaubon's similarly unchanging pitch of voice provides perhaps the best example of George Eliot's reliance on music to transcend authenticity. Casaubon proves to have many important shortcomings as the novel progresses, but authenticity is not one of them. Dorothea is not bothered by a lack of authenticity on Casaubon's part; it is rather his "matter-of-course . . . tone of dismissal with which he treat[s] what to her were the most stirring thoughts" (p. 196). Even more than his indifference to music, it is Casaubon's "measured official tone"-one like "a clergyman reading according to the rubric"- that indexes his anemic sympathy for anything beyond his own scholarship (p. 197). Casaubon's weak voice, like his debilitated heart, has no Schopenhauerian musicality. He is incapable of feeling beyond himself, beyond the academic and solipsistic "centre of his own world" (p. 85). It is an apt and well-sustained irony, then, that Casaubon, with his self-described 
"fastidious[ness] in voices," has only one definitively unmusical mode of speaking, and since it is he who spends most of his life toiling in the "morass of authorship"-searching ridiculously for a single, but decidedly unmelodic "Key to All Mythologies" (pp. $17,85,63$, emphasis added).

By contradistinction, authenticity as well as sympathy characterizes Middlemarch's more musically intoned voices. Ladislaw's voice "seem[s] a gay little chime" next to Casaubon's icy, unchanging tone, and it is Ladislaw whom the narrator allows us to hear singing lyric songs on his way to church (p. 212). George Eliot also draws our attention to Lydgate's enthusiastic voice early in the novel as he outlines his plan to build a new fever hospital and a medical school in Middlemarch. In the paragraph immediately following this unprecedented vision, the narrator describes Lydgate's baritone voice in more detail than at any other point in the novel: "One of Lydgate's gifts was a voice habitually deep and sonorous, yet capable of becoming very low and gentle at the right moment" (p. 124). George Eliot's rendition of the benevolent hospital plan in the unequivocally musical voice here connects the range of Lydgate's musical responsiveness and his capacity for sympathy in a unified yet distinctly aural description.

No character has a more sympathetic disposition or a more singularly musical voice than Dorothea Brooke. Certainly the "birdlike modulation" of her speaking voice sounds very different from Celia's staccato at the beginning of the novel, but it is her likeness to a "later-born" Saint Theresa in the Prelude which establishes the tone of religious sympathy that we hear in Dorothea's voice (p. 223). With Dorothea, above all other characters, the symbol of sympathy becomes literalized, but not so much as an expression of authenticity, as Byerly suggests, but as an expression of sympathy. George Eliot literalizes Dorothea's "fanatic" sympathy within the musical range of Dorothea's voice-a range that moves harmoniously from "the saddest recitative" to the "full[est] of feeling" at the same time (pp. 208, 209). In this way, Dorothea's voice ceases to be like music simply because it is music in the Schopenhauerian sense of aural becoming. The "melodious fragments" of her voice enchant Ladislaw, and he comes to associate Dorothea's voice with "a soul that had once lived in an Aeolian harp” (pp. 209, 80). Caleb Garth makes a still more organic and striking association between Dorothea's musicality and her sympathy precisely because his is not a mimetic association at all; for Garth, there is no distinction between sympathetic emotion and music. In a Schopenhauerian moment of sympathetic thing- 
in-itselfness, Garth actually hears "bits [of] the Messiah" while Dorothea explains her passionate desire to improve humankind with "a great many good cottages" (p. 552).

Because critics have agreed that "[t]he narrator is the key to nineteenth-century realist fiction," the musical function performed by George Eliot's narrator deserves exploration. ${ }^{29}$ Her narrator amplifies the sounds, not merely the sights, of Middlemarch, and so we hear sympathy in places we might otherwise have been least inclined to listen for it. The narrative voice becomes most musical when it is called upon to describe those states of consciousness that are impossible to reach within the semiotic confines of language. This is a distillation of Schopenhauer's belief that words can "speak only of shadows," whereas music "speaks of the thing itself" ( $W W, 1: 333)$. For example, we cannot, and therefore do not, gain access to the "tone of fervid veneration [and] religious regard" with which Garth speaks of his vocation (p. 250). Instead, George Eliot creates an aural experience that actually "is" Garth's sense of sublimity engendered by the sounds of his physical work:

Caleb Garth often shook his head in meditation on the value, the indispensable might of that mryiad-headed, myriad-handed labour by which the social body is fed, clothed, and housed. It had laid hold of his imagination in boyhood. The echoes of the great hammer where roof or keel were a-making, the signal-shouts of the workmen, the roar of the furnace, the thunder and plash of the engine, were a sublime music to him; the felling and lading of timber, and the huge trunk vibrating star-like in the distance along the highway, the crane at work on the wharf, the piled-up produce in warehouses, the precision and variety of muscular effort wherever exact work had to be turned out, - all these sights of his youth had acted upon him as poetry without the aid of poets, had made a philosophy for him without the aid of philosophers, a religion without the aid of theology.

(pp. 250-1)

Physical work is a "sublime music" to Caleb Garth, and so the narrative voice used to describe his experience has the lyrical style, rhythmic intonation, and melodic progression of music itself. The lengthy second sentence of this famous description, like Shencker's view in Harmony, arouses a sense of undulating 
desire and postpones gratification until the final set of clauses. The onomatopoeically constructed phrasing more generally produces the sounds of the actual work it describes. The lyrical ceases to describe in a merely external sense; instead, it partakes of the aural reality it describes: the echoes of the great hammer where roof or keel were "a-making," the roar of the furnace, and the plash of the engine. Moreover, we hear alliterative dissonance and consonance vividly throughout: the felling and lading of timber, the crane at work on the wharf, the piled-up produce. This sustained alliterative emphasis creates a musical rhythm of heightened anticipation as it withholds and temporarily violates resolution until the end of the paragraph when, like our experience with music, we feel more richly satisfied by the exposition.

Although George Eliot mentions how the "sights of [Caleb Garth's] youth had acted upon him," the remarkable sounds of his experience make the ocular seem ancillary. Caleb Garth, like George Eliot's Jubal, meditates on the sublime experience where the aural replaces the ocular. Jubal watches the hammer until his eyes become "glad with something that they [cannot] see," until he listens to "some melody, / Wherein dumb longings [of] inward speech" are found. Schopenhauer asserts that "music is the language of feeling and of passion, as words are the language of reason" ( $W W, 1: 335-6)$. George Eliot applies this dictum to nearly all of her characters in Middlemarch. Her most verbose characters-Mr. Brooke, Rosamond, and Casaubon-are moved by reason and by words, but, quite noticeably, not by passion, sympathy, or music. On the other hand, characters such as Dorothea, Lydgate, and Caleb Garth understand very little in terms of the technical foundations of music, but yet it is they who are most touched by what George Eliot calls "the inward speech" of melody.

Dorothea cannot put words to her sublime experience in front of the great organ at Freiberg. It is not surprising that Middlemarch's honest laborer, Caleb Garth, attends oratorios whenever he can afford them. Perhaps what is more Schopenhauerian is Garth's passionate inability to express his musical experiences with the signs and signifiers of language. Instead, Caleb returns from the oratorio "with a profound reverence for this mighty structure of tones, which made him sit meditatively, looking on the floor and throwing much unutterable language into his outstretched hands" (p. 553). Like Jubal, Caleb Garth seems satisfied with an "inward speech" that his words cannot explain and that his eyes cannot see. The sense of Caleb Garth's 
semantically indescribable and rapturous interactions with music in Middlemarch closely resemble Lawrence Kramer's notion of song in Music and Poetry (1984): "Through song, usually the song of a disincarnate voice or of a figure touched by divinity, language is represented as broaching the ineffable." 30

Harry E. Shaw and others have noted that the interpretation of novelistic realism has had divergent meanings for critics during the last half century. ${ }^{31}$ To the extent that there is a prevailing critical model concerning George Eliot's realism, though, interpretation has been traditionally located in the ocular. ${ }^{32}$ External observation has often provided the basis for realism's natural (and historical) association with perception, and so it is not remarkable that perception is often considered "the criterion for the validity of a representation." ${ }^{33}$ Hina Nazar notes how "a focus on the trope of ocular vision widely employed in George Eliot's novels is not in itself problematic," given the long history of sight-based criticism. ${ }^{34}$ What is problematic, as Nazar points out, is the "frequent and often silent move made by critics to equate representation and particular perception." ${ }^{35}$ As an example of this, she identifies how Audrey Jaffe, in a footnote to her recent Scenes of Sympathy (2000), asserts that "visuality . . . may thus be understood as a metaphor for representation and knowledge: what can be known at any given time is what can be seen." 36

In Middlemarch, the realism we encounter is not only visual and external; it is also aural and intensely internal. George Eliot's emphasis on musicality displays the more general privilege she gives to sound in the novel. It is not so much the language, but the sound-the musicality beyond the language-that helps us experience a Schopenhauerian sense of reality. For this reason, the musical realism in the novel seems at least one crucial step removed from interpretation that is based solely on George Eliot's optical reliability. Miller maintains that the deconstructive powers of figurative language undo George Eliot's "attempt to make a complete, and completely coherent, picture of human life." 37 Miller is certainly correct in his observation that "if we can seldom say what a thing is without saying it is something else . . then there is no way to avoid the ever present possibility of altering the meaning by altering the metaphor." ${ }^{8}$

I am suggesting that the music in Middlemarch offers an alternate mode of realism precisely because music relies neither on constructed image nor on metaphorical language for its objectivity. The musical elements remain uncorrupted by what has been referred to as George Eliot's "parabolic' method": the 
"seeing of one thing in the 'light' of another."39 I do not wish to evaluate the "completeness" of Middlemarch's realism in light of its musicality but rather to consider how the Schopenhauerian influence complicates the traditional realist association between seeing and knowing in Middlemarch. ${ }^{40}$

As I have attempted to show, the grammar of perspective that governs pictorial realism is less applicable to music because music exists in a place beyond language and because it requires fewer symbolic, re-presentational forms; it is closer to the essence of the thing itself. In "Notes on Form in Art" (1868), George Eliot writes that "boundary or outline and visual appearance are modes of Form which in music and poetry can only have a metaphorical presence." ${ }^{41}$ George Eliot's "battle ground of conflicting metaphors" then ceases to pose so much of a problem in the aural world of Middlemarch since conflicting and dissonant sounds are absolutely necessary for the existence of musical harmony. ${ }^{42}$ Schopenhauer concedes, in terms very similar to Miller's, that the observable world is "a constant battle-field" of one will, "whose inner contradiction with itself becomes visible" (WW, 1:344). Music, for Schopenhauer and George Eliot, offers an important alternative to the visible contradictions of the observable world. The Westminster Review article from 1853 asserts that Schopenhauer's ideal artist "is he whose heart beats with sympathy for all creatures around him . . . acknowledging them as manifestations of the same great Will as himself." ${ }^{3}$ This is why realism in Middlemarch is not solely a matter of "keen vision"; it is also a correlative "adjustment of tones and rhythm to a climax, apart from any imitation." 44

\section{NOTES}

I am grateful to Karen Chase, Paul Cantor, and Robin Field for generously commenting on earlier versions of this essay.

${ }^{1}$ George Eliot, "The Legend of Jubal" (1869-70), in Collected Poems, ed. Lucien Jenkins (London: Skoob Books Publishing, 1989), pp. 91-114, 98.

${ }^{2}$ George Eliot, Middlemarch, ed. Rosemary Ashton (Harmondsworth: Penguin, 1994), p. 159. Subsequent references to Middlemarch will be to this edition and will appear parenthetically in the text by page number.

${ }^{3}$ See Robert L. Jacobs, "The Role of Music in George Eliot's Novels," The Music Review 45, 3-4 (August-November 1984): 277-82.

${ }^{4}$ George Levine, "Introduction: George Eliot and the Art of Realism," in The Cambridge Companion to George Eliot, ed. Levine, Cambridge Companions to Culture (Cambridge and New York: Cambridge Univ. Press, 2001), pp. 1-19, 16. 
${ }^{5}$ The expression comes from a treatise on Britain by the German author Oscar A. H. Schmitz entitled Das Land ohne Musick: Englische Gesellschafsprobleme, published in Munich in 1914; later translated into English by H. Herzl (London: Jarrolds, 1925). For a discussion of how Britain's most promising young musicians faced the peculiarly English hazard of neglecting their own compositions while trying to perform the administrative details of "teaching" music, see D. J. Smith, "Music in the Victorian Novel," Kenyon Review 25, 3 (Summer 1963): 517-32; Eric D. Mackerness, A Social History of English Music (London: Routledge and Kegan Paul, 1964), pp. 61-79; S. G. Peskin, "Music in Middlemarch," ESA 23, 2 (September 1980): 75-81; and Phyllis Weliver, Women Musicians in Victorian Fiction, 1860-1900: Representations of Music, Science, and Gender in the Leisured Home (Aldershot and Burlington VT: Ashgate, 2000), pp. 19-58.

${ }^{6}$ Most recently, Ruth A. Solie makes this point in her review article ("No 'Land Without Music' After All," VLC 32, 1 [2004]: 261-76). See also Bennett Zon's preface in The Idea of Music in Victorian Fiction, ed. Sophie Fuller and Nicky Losseff (Aldershot and Burlington VT: Ashgate, 2004), p. viii.

${ }^{7}$ Key texts include Calvin S. Brown, Music and Literature: A Comparison of the Arts (Athens: Univ. of Georgia Press, 1948); and Percy M. Young, "George Eliot and Music," Music and Letters 24, 2 (April 1943): 92-100. Young's article provides an early example of the attention to Eliot's musicality, and it also establishes a critical tradition that has come to explore and analyze only her most professionally "musical" novels. Young's essay concentrates almost entirely on The Mill on the Floss and Daniel Deronda. Shirley Frank Levenson analyzes Eliot's musicality remarkably—but only in Daniel Deronda ("The Use of Music in Daniel Deronda," NCF 24, 3 [December 1969]: 317-34). Eliot's connection to music has been the subject of several more recent studies, but her professional musicians continue to draw the most attention. Alisa Clapp-Intyre investigates the textual and sociohistorical significance of songs and musical scores (as well as Schopenhauerian influence) in Angelic Airs, Subversive Songs: Music as Social Discourse in the Victorian Novel (Athens: Ohio Univ. Press, 2002). In her introduction, Clapp-Intyre explains Middlemarch's absence from her study because it "is only sparsely filled with specific musical allusions and these do not invoke a central genre" (p. xxi). Another example, Delia Da Sousa Correa's George Eliot, Music, and Victorian Culture (New York: Palgrave Macmillan, 2003) discusses Middlemarch but devotes separate chapters to The Mill on the Floss and Daniel Deronda.

${ }^{8}$ Eliot's intense scholarly interest in German philosophy is, of course, often associated with the moral seriousness of her fiction. She spent much of her early years reading Georg Wilhelm Friedrich Hegel, Immanuel Kant, and Friedrich Schiller, and critics often point out how her translations of Baruch Spinoza, Otto Strauss, and Ludwig Andreas Feuerbach informed her secular but fervent belief in the human need for sympathy. For the lack of Schopenauerian-influenced analyis, see Beryl Gray, George Eliot and Music (New York: St. Martin's, 1989), which includes chapters on The Mill on the Floss, Middlemarch, and Daniel Deronda but fails to mention Arthur Schopenhauer. Correa lists Schopenhauer in three brief notes (pp. 222n2; 228n143; 223n197). Clapp-Intyre discusses Schopenhauer, but not in conjunction with Middlemarch (pp. 3-5, 125-6). E. A. McCobb analyzes Schopenhauerian 
influence but only in Daniel Deronda ("The Morality of Musical Genius: Schopenhauerian Views in Daniel Deronda," FMLS 29 [1983]: 321-30). Weliver comes closest to my argument. Chapter 5 of her study treats Schopenhauer, but it focuses most heavily on the character of Maggie in The Mill on the Floss. Chapter 6 analyzes sexual selection and music in Middlemarch and Daniel Deronda. Jonathan Taylor discusses Schopenhauer amply but, as his title suggests, focuses on professional musicianship in "The Music Master and 'the Jew' in Victorian Writing: Thomas Carlyle, Richard Wagner, George Eliot, and George Du Mauier," in Fuller and Losseff, pp. 225-44.

${ }^{9}$ Schopenhauer, The World as Will and Idea, 3 vols. (AMS Press: New York, 1977), 1:330. Subsequent references to this text will be to this edition and will be cited parenthetically in the text as $W W$ by volume and page number.

${ }^{10}$ [John Oxenford], "Iconoclasm in German Philosophy," Westminster Review, n.s., 59, 3 (January and April 1853): 388-407, 407.

${ }^{11}$ Oxenford, p. 393.

${ }^{12}$ Oxenford, p. 405.

${ }^{13}$ George Eliot, "[Westward Ho! And Constance Herbert]," Westminster Review 64 (July 1855): 288-96, in The Essays of George Eliot, ed. Thomas Pinney (New York: Columbia Univ. Press, 1963), pp. 123-36, 126.

${ }^{14}$ Thomas Carlyle, On Heroes, Hero-Worship, and the Heroic in History (Berkeley: Univ. of California Press, 1993), p. 72.

${ }^{15}$ Ibid.

${ }^{16}$ Weliver, p. 152.

${ }^{17}$ Susan McClary, Feminine Endings: Music, Gender, and Sexuality (Minneapolis and Oxford: Univ. of Minnesota Press, 1991), p. 12.

${ }^{18}$ McClary, p. 8.

${ }^{19}$ Arnold Schoenberg, Theory of Harmony, trans. Roy E. Carter (Berkeley: Univ. of California Press, 1983), p. 96, qtd. in McClary, p.11.

${ }^{20}$ George Eliot, “Jubal,” p. 98.

${ }^{21} \mathrm{~J}$. Hillis Miller, "Optic and Semiotic in Middlemarch," in The Worlds of Victorian Fiction, ed. Jerome H. Buckley (Cambridge MA and London: Harvard Univ. Press, 1975), pp. 125-45, 137. Miller's article provides a discussion of the extensive use of optical metaphors in Middlemarch.

${ }^{22}$ George Eliot, Impressions of Theophrastus Such, ed. Nancy Henry (London: Pickering and Chatto, 1994), p. 110.

${ }^{23}$ McClary, pp. 13, 12.

${ }^{24}$ Heinrich Schenker, Harmony, ed. Oswald Jonas, trans. Elizabeth Mann Borgese (Cambridge MA: MIT Press, 1973), p. 28, qtd. in McClary, p. 12.

${ }^{25}$ Barbara Hardy, "Implication and Incompleteness: George Eliot's Middlemarch," in The Victorian Novel: Modern Essays in Criticism, ed. Ian Watt (Oxford and New York: Oxford Univ. Press, 1971), pp. 289-310. 310.

${ }^{26}$ McClary, p. 13.

${ }^{27}$ Several studies have considered the significance of voice in Eliot's fiction. See Levenson and Karen B. Mann, The Language that Makes George Eliot's Fiction (Baltimore and London: Johns Hopkins Univ. Press, 1983), pp. 62-4, 70-89.

${ }^{28}$ See Alison Byerly, “The Language of the Soul': George Eliot and Music," NCF 44, 1 (June 1989): 1-17, 16. 
${ }^{29}$ Harry E. Shaw, Narrating Reality: Austen, Scott, Eliot (Ithaca and London: Cornell Univ. Press, 1999), p. 218.

${ }^{30}$ Lawrence Kramer, Music and Poetry: The Nineteenth Century and After, California Studies in Nineteenth-Century Music (Berkeley, Los Angeles, and London: Univ. of California Press, 1984), p. 2.

${ }^{31}$ Shaw, p. xii.

${ }^{32}$ Bernard J. Paris's influential study of George Eliot explores the relation of her realism to her scientific "picture of man" in Experiments in Life: George Eliot's Quest for Values (Detroit: Wayne State Univ. Press, 1965), p. 4. The interpretation of George Eliot's artistic imagery has grown into a critical tradition in its own right. See Hugh Witemeyer's study of pictorial images in George Eliot and the Visual Arts (New Haven and London: Yale Univ. Press, 1979). Katherine Kearns analyzes more generally the relationship of realism to the "burden of sightedness" in Nineteenth-Century Literary Realism: Through the Looking-Glass (Cambridge: Cambridge Univ. Press, 1996), p. 2.

${ }^{33}$ Hina Nazar, "Philosophy in the Bedroom: Middlemarch and the Scandal of Sympathy,” YJC 15, 2 (Fall 2002): 293-314, 298.

${ }^{34}$ Ibid.

${ }^{35}$ Ibid.

${ }^{36}$ Audrey Jaffe, Scenes of Sympathy: Identity and Representation in Victorian Fiction (Ithaca and London: Cornell Univ. Press, 2000), p. 15n23.

${ }^{37}$ Miller, p. 144.

${ }^{38}$ Ibid.

${ }^{39}$ Miller, p. 139.

${ }^{40}$ See Hardy, p. 310.

${ }^{41}$ George Eliot, "Notes on Form in Art" in Selected Critical Writings, ed. Rosemary Ashton (Oxford: Oxford Univ. Press, 1992), p. 356.

${ }^{42}$ Miller, p. 137.

${ }^{43}$ Oxenford, p. 405.

${ }^{44}$ George Eliot, "Notes on Form in Art,” p. 357. 